IRSH 52 (2007), pp. I05-I09 DOI: I0.1017/S00208590060028 I I

(C) 2007 Internationaal Instituut voor Sociale Geschiedenis

\title{
Global Movements, Internal Migration, and the Importance of Institutions
}

\author{
DAVID FELDMAN
}

In May I928 The Watling Resident, a local newspaper directed at a readership among the inhabitants of a working-class estate created by the London County Council on the north-western outskirts of the city, published its first issue. It took the opportunity to represent what it saw as its readers' urgent and existential difficulties: "We have been torn up by the roots and rudely transplanted to foreign soil." According to the newspaper, these painful feelings of displacement were voiced "over and over again" by people living on the new estate. ${ }^{\text {I }}$ These migrants and their mouthpiece spoke and wrote in terms that prefigure the pioneering historical work of Oscar Handlin or suggest they were of one mind with the Chicago School of sociology. In this light it is remarkable that these migrants were not recent arrivals from Poland, or even from Ireland or Scotland; rather they had moved to the estate from inner London, and more than half had previously lived a few miles away in the north London boroughs of St Pancras, Islington, Finsbury, and Paddington.

This episode suggests that we might extend our understanding of both internal and international migration if we examine both within the same conceptual field. Yet historians and social scientists have generally discussed these streams as separate phenomena. More promising, however, are those analyses that point to the connections between local and transnational movements. For international migrations have local origins. These have been noted, in particular, by scholars who remain sceptical about the explanatory force attributed to long-distance wage differentials by some economic historians and who also attend to the social and institutional histories that produced transatlantic and other migrations. ${ }^{2}$ These historians acknowledge the role of institutions such as the family in determining who stays and who leaves, the significance of networks of kin and established channels of migration in shaping patterns of international mobility, and the role of other institutions such as mutual aid societies and labour recruitment enterprises in shaping both migration and integration.

I. R. Durant, Watling (London, I939), pp. 22 and I 2 I.

2. See for example, A. McKeown, "Global Migration, I846-1940", Journal of World History, is (2004), pp. I5 5-I89; Leslie Page Moch, Moving Europeans: Migration in Western Europe since I650 (Bloomington, IN, 2003). 
Each of these elements, chiefly remarked on in the context of international migration, also influenced the history of internal migration in nineteenth-century Britain. Here too models of migration that account for mobility as a series of responses to wage differentials are wanting. They are blunt instruments able to account for a general tendency but unable to tell us why some people responded to opportunities and others did not, or why particular groups of migrants ended up in particular places. We know most about the family economy as a ruthless system. Sons and daughters with nothing to inherit, from Lancashire to Devon, were ejected and left to join the tide of urban migrants. Girls were particularly vulnerable. With the collapse of numerous rural trades, employment for girls was particularly scarce and many were forced by circumstances and their fathers to leave home. Accordingly, it was girls dispatched into household service who made the greatest single contribution to the outflow of rural population. ${ }^{3}$ Irish migration, some of which remained within the British Isles, and most of which went far further afield, illustrates the ways in which local and international migrations were closely related. Here too family and household were crucial influences. David Fitzpatrick has observed, "Since migration normally occurred shortly before marriage became probable, and close to the moment when household control was transferred from one generation to another, the decision to migrate may be treated as the outcome of a choice between marriage and succession, celibacy and dependency in Ireland, and departure."4

To a remarkable extent the history of internal migration continues to be pursued in the shadow of E.G. Ravenstein, who first wrote on the subject I 30 years ago. Ravenstein was spurred by William Farr's remark that migration, unlike other demographic events "appeared to go on without any definite law". After scrutinizing the birth tables in the I87 I and I88 I censuses for Britain, as well as data from other censuses taken elsewhere in Europe and North America, Ravenstein came up with a series of claims, that he called laws. He stated, for example, that the majority of migrants go only a short distance and that migration proceeds step by step, that women are more migratory than men within states and that men are more likely to emigrate. The main cause of migration, he stated was economic, and migrants, he observed, tended to travel from agricultural districts to centres of industry and commerce. By his own account, Ravenstein was

3. M. Anderson, Family Structure in Nineteenth-Century Lancashire (Cambridge, I97I), pp. 85-86, 95-96; R.Wall, "Work, Welfare and the Family: An Illustration of the Adaptive Family Economy", in L Bonfield, R. Smith, and K. Wrightson (eds), The World We Have Gained (Oxford, I986), pp. 272-273; W.A. Armstrong, "The Flight from the Land”, in G. Mingay (ed.), The Victorian Countryside, I (London, I98I), p. I24; and K. Snell, Annals of the Labouring Poor (Cambridge, 1985), pp. 326-327.

4. D. Fitzpatrick, "Emigration, I 8 10-70", in W.E. Vaughan (ed.), A New History of Ireland, V, Ireland under the Union, I, I80I-70 (Oxford, I989), p. 606. 
trying to emulate studies of other demographic indicators. ${ }^{5}$ But migration is an aspect of demography different from birth and death. Of course, both birth and death rates are the outcomes of social processes as well as natural causes, but whereas birth and death are necessarily a part of any life, the same cannot be said of migration. Yet the tendency of Ravenstein's influence has been to place migration in the realm of nature rather than of society.

Classical economics has provided a similar legacy. The influence of classical economics is in many ways compatible with Ravenstein's laws. "Free" migration is seen as the sum of the choices made by income maximizing individuals as they responded to the pulls and pushes of the labour market. Migration is thus seen as a natural process of cause and effect, the outcome of external social forces acting upon a human nature bomo economicus - which is taken as given. But as a glance at the recent history of the European Union and the phenomenon of labour migration within it will remind us, free migration is a creation of governments not of nature. This applies to internal migration as much as it does to international movements within and across continents. In the case of England, there were no barriers to internal movement in the eighteenth and early nineteenth centuries, but there were penalties imposed by the Poor Law and, specifically, by the law of settlement. By the beginning of the eighteenth century, the Poor Law was well established. It operated as a national system, supported by compulsory local taxation, its day-to-day operation administered locally by the inhabitants of a district. Within this system the question of which parish should take responsibility for which poor person was a matter of great importance, for both tax payers and anyone who might one day stand in need of poor relief. It was to this question that the law of settlement provided answers. As a result, if people tried to draw relief from a parish other than the one to which they "belonged", for example, if they migrated and then fell on hard times, they could be physically removed and, in effect, deported to another parish.

Historians disagree on the extent to which the law of settlement did, in fact, constrain migration. However, figures such as Adam Smith and Jeremy Bentham were in no doubt as to its effects and both thought the law confined workers to their parish. By the i 840 s the law of settlement had become one reason why, in the eyes of poor law reformers the labour market remained radically imperfect. Above all, it appeared to offer a reason why a mass of underemployed labourers remained in the rural south of the country. Reformers criticized the law of settlement and the practice of removal not only as economic fetters but also as barriers to

5. E.G. Ravenstein, "Census of the British Isles, I871, Birthplaces and Migration”, Geographical Magazine, 3 (1 876), pp. I73-177; idem, "The Laws of Migration", Journal of the Royal Statistical Society, 2 (1885), pp. 167-235. 
moral improvement, freedom, and manly independence. They conceived it as a form of bondage. According to one of their number, George Coode, in a small or over-populated parish the settled labourer was not a free man: "He knows that the parish by the protection of removal [ie by the law of settlement] has bound him to its soil [...] no such feeling as grows out of connexions freely sought, freely maintained and, if unsuitable, freely abandoned." 6 Eventually in I 846 a law was passed preventing the removal of anyone who had lived in a parish for five years, and over the next two decades the law of settlement was further attenuated. These were political interventions that to some extent helped create an open labour market and more certainly had a vital impact on the experiences of migrants within that market.

The political framework for internal migration did not disappear with the law of settlement but was constantly reforged. The movement to the suburbs that framed urban development in the first half of the twentieth century was enabled by the state in vital ways. Of course, the erection of local-government housing estates, such as the one built at Watling, was part of this process. But the state was a key actor in private development too. The expansion of London suburbia, for example, was tied to the parallel expansion of the underground rail network that, in turn, was enabled by Treasury guarantees. The attraction of the gadget-rich modernity of the suburbs was enhanced by the creation of the national grid and the drop in the price of electricity that followed. Most fundamentally, low interest rates, set by the government, fuelled the housing boom of the I930s without which there would have been no move to the suburbs by individual homeowners. ${ }^{7}$

This discussion has focused on some analytical connections between internal and international migrations and the ways in which both are more complex phenomena than some economic histories would have us believe. ${ }^{8}$ But the unfortunate influence of classical economics on our understanding of migrations goes significantly further than this. Repeatedly in nineteenth-century Britain, the economy's failure to act in ways that economic theory predicted and prescribed was explained away with reference to the peculiar cultural or racial characteristics of a migrant minority. The Irish in nineteenth-century Britain were widely identified as the source of urban disorder and moral contagion. In this respect, Engels's famous denunciation of the living conditions and collective personality of the Irish in Manchester, published in I844, echoed the conventional wisdom established by a legion of commentators and investigators. In particular, Engels

6. On this see D. Feldman, "Migrants, Immigrants and Welfare from the Old Poor Law to the Welfare State", Transactions of the Royal Historical Society, I3 (2003), pp. 83-95.

7. Idem, "Migration", in M. Daunton (ed.), The Cambridge Urban History of Britain, III (Cambridge, 2000), pp. 202-203.

8. On this, see McKeown, "Global Migration”. 
was influenced by J.P. Kay's The Moral and Physical Condition of the Working Classes Employed in the Cotton Manufacture in Manchester (I 832 ).

The central argument of Kay's pamphlet was that the dreadful social conditions that beset Manchester were not inherent to the factory system or to commercial society but that, rather, they were outgrowth of Irish immigration and the disastrous impact of the Irish both on the labour market and the English labouring poor. The structural shortcomings of an economic and social system were thus evaded by invoking the cultural peculiarities of the Irish nation or "race". This was a characteristic manoeuvre which can be found elsewhere, for example, in the ways that the failures of the post-emancipation Caribbean economies were blamed on the former slaves' reluctance to work, or the ways in which sweated labour conditions among male workers in late nineteenth-century London (an impossibility according to the economic theory of the time) was attributed to the unique and undesirable qualities of Jewish immigrants. ${ }^{9}$ The prestige of classical economics has been one of the influences that have rendered cultural and racial understandings of the consequences of migration so persuasive. The peculiarities of immigrants have been called upon to explain why the real economy has failed to fulfil the predictions of economic theory.

This is a phenomenon that runs across the distinction between immigrants and internal migrants. Indeed, the case of the Irish itself mocks the distinction: as the relationship of Ireland itself changed in I 80I, with the Act of Union and in 1922 with the creation of the Irish Free State so too did the status of the Irish living in England, Wales, and Scotland. But the case of the Irish in nineteenth-century Britain does also illustrate that racialized responses to immigrants do not arise only in the cases of long-distance migrants. Just as our understanding of the dynamics of migration will be foreshortened if we categorically separate internal migration from international migration, so too our analyses of receiving societies and of integration processes will be limited a similar way. Of course, the extent to which internal migrants will be seen as "foreign" will depend to an important degree on processes of national integration. It would be foolish to suggest that there are no distinctions between internal migrants and immigrants, but our understanding of both may advance if we interrogate their similarities and differences within particular historical contexts. 